\title{
Du mouvement dans l'école ... Histoire d'une lutte sourde et implacable
}

\section{Denis Daniel}

\section{(2) OpenEdition \\ Journals}

Édition électronique

URL : http://journals.openedition.org/trema/2490

DOI : $10.4000 /$ trema. 2490

ISSN : 2107-0997

Éditeur

Faculté d'Éducation de l'université de Montpellier

Édition imprimée

Date de publication : 24 octobre 1997

Pagination : 89-106

ISSN : 1167-315X

Référence électronique

Denis Daniel, « Du mouvement dans l'école ... Histoire d'une lutte sourde et implacable », Tréma [En ligne], Hors série $N^{\circ} 1$ | 1997, mis en ligne le 03 janvier 2011, consulté le 20 avril 2019. URL : http:// journals.openedition.org/trema/2490 ; DOI : 10.4000/trema.2490

Ce document a été généré automatiquement le 20 avril 2019

Trema 


\title{
Du mouvement dans l'école ... Histoire d'une lutte sourde et implacable
}

\author{
Denis Daniel
}

\section{RÉSUMÉS}

L'enjeu de l'école, en général, et de l'éducation physique scolaire en particulier est-il politique? Il semblerait que non dès lors qu'est pris en compte le dogme constitutif, issu des écoles des frères des écoles chrétiennes, du «silence et de l'immobilité», qui résiste à tout principe de réforme quand le contexte impose la méthode simultanée. Le champ de l'éducation du corps dans l'école, jusqu'alors, n'aurait fait que transformer des pratiques de mouvement pour les faire souscrire à ce dogme constitutif.

Are the stakes of school, and school PE in particular, political? It would appear not to be so insofar as is taken into account the initial dogma of "silence and immobility", (tracing its origins to the schools of The Christian Brothers'), which is impervious to any attempt at reform even when the context would demand the simultaneous method. The field of the education of the body at school, would have to this day, simply transformed practices of bodily movement in order to make them adhere to this original dogma.

\section{INDEX}

Mots-clés : immobilité, institution scolaire, silence

Keywords : immobility, school as an institution, silence 


\section{AUTEUR}

DENIS DANIEL

Centre de recherches sur les cultures sportives, IUFM de Versaille, université de Paris XI 